\title{
Cardioplexol, a new cardioplegic solution for elective CABG
}

\author{
K Kairet $^{1^{*}}$, J Deen ${ }^{1}$, L Vernieuwe ${ }^{1}$, A de Bruyn ${ }^{1}$, S Kalantary ${ }^{1}$, I Rodrigus ${ }^{2}$ \\ From 23rd World Congress of the World Society of Cardio-Thoracic Surgeons \\ Split, Croatia. 12-15 September 2013
}

\begin{abstract}
Background
Cardioplexol $^{\circledR}$ (Swiss Cardio Technologies) is a hyperkalemic, low-dose, single-shot cardioplegic solution which offers immediate asystole of the heart, maintenance up to 90 minutes and immediate reversal of asystole after release of cross clamp. Intermittent crossclamping with Lidoflazine is the current operative technique used in our center. Main question was whether Cardioplexol is an efficient, safe, easy-to-use and worthy alternative to Lidoflazine in elective isolated CABG in low-risk patients. Primary outcomes are heart enzymes (cTnI and $\mathrm{CK}-\mathrm{MB}$ ) and secondary outcomes are operation times, length of stay, major complications and in-hospital mortality.
\end{abstract}

\section{Methods}

From December 2011 to May 201340 patients, with LVEF $\geq 50 \%$, EuroSCORE II $<3,5 \%$ and no severe systemic disease, underwent elective CABG and were consecutively randomized to intermittent crossclamping (ICC; $n=20)$ or Cardioplexol (CPX; $n=20)$. All were operated on by the same surgeon.

\section{Results}

There was no significant difference in age (CPX 71.04 \pm 8.54 ; ICC 67.25 \pm 9.90 ), EuroSCORE II (CPX 1.19 \pm 0.63 ; ICC $1.11 \pm 0.46$ ) or number of distal anastomoses (CPX $2.95 \pm 0.51$; ICC $3.15 \pm 0.745)$. We found no significant difference for maximum cTnI (CPX $3.38 \pm 1.50$; ICC 4.59 \pm 4.23 ) or maximum CK-MB (CPX $23.99 \pm 13.95$; ICC $25.50 \pm 20.10$ ). ECC time (CPX 57.55 \pm 11.93 ; ICC 67.20 \pm 21.78 ) and cross-clamp time (CPX 24.62 \pm 1.31 ; Lido $22.76 \pm 1.49)$ were not significantly different. Neither

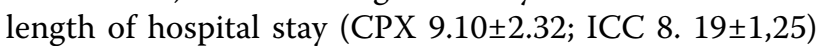

\footnotetext{
* Correspondence: koen.kairet@student.ua.ac.be

${ }^{1}$ University of Antwerp, Belgium

Full list of author information is available at the end of the article
}

nor postoperative complications (CPX $1.25 \pm 0.78$; ICC $0.85 \pm 0.67)$ showed significant difference. There was no in-hospital mortality.

\section{Conclusion}

In this elective CABG population with low risk, Cardioplexol offered good myocardial protection, with comparable primary and secondary outcomes. Further studies are needed to expand its use.

\section{Authors' details}

${ }^{1}$ University of Antwerp, Belgium. ${ }^{2}$ Department of Cardiac Surgery, Antwerp University Hospital, Belgium.

Published: 11 September 2013

\section{doi:10.1186/1749-8090-8-S1-P120}

Cite this article as: Kairet et al:: Cardioplexol, a new cardioplegic

solution for elective CABG. Journal of Cardiothoracic Surgery 2013 8(Suppl 1):P120.

\section{Biomed Central}

(c) 2013 Kairet et al; licensee BioMed Central Ltd. This is an Open Access article distributed under the terms of the Creative Commons Attribution License (http://creativecommons.org/licenses/by/2.0), which permits unrestricted use, distribution, and reproduction in any medium, provided the original work is properly cited.

Submit your next manuscript to BioMed Central and take full advantage of:

- Convenient online submission

- Thorough peer review

- No space constraints or color figure charges

- Immediate publication on acceptance

- Inclusion in PubMed, CAS, Scopus and Google Scholar

- Research which is freely available for redistribution

Submit your manuscript at www.biomedcentral.com/submit

\section{( Biomed Central}

